\title{
Quality of Life of Mothers of Children with Intellectual Disability: Do Social Support, Maternal Stress and Socio- Economic Status Play a Role?
}

\author{
Udeme Samuel Jacob ${ }^{1,2}$, Jace Pillay ${ }^{3}$, Bolanle Misitura Oyundoyin ${ }^{4}$ \\ ${ }_{1}^{1}$ Postdoctoral Research Fellow, South African Research Chair: Education and Care in Childhood, \\ Faculty of Education, University of Johannesburg, South Africa \\ ${ }^{2}$ Department of Special Education, Faculty of Education, University of Ibadan, Nigeria \\ https://orcid.org/0000-0002-3234-8226 \\ Email: udeme01@gmail.com
}

${ }^{3}$ South African Research Chair: Education and Care in Childhood, Faculty of Education, University of Johannesburg, South Africa https://orcid.org/0000-0002-9432-6014

Email: jacep@uj.ac.za

4Department of Home Science and Management, College of Food Science and Human Ecology, Federal University of Agriculture, Abeokuta https://orcid.org/0000-0002-9080-4664 Email: oyundoyinbm@funaab.edu.ng

\begin{tabular}{ll}
\hline Article History: & Abstract: This study investigates the influence of \\
Received: 2021-03-24 & perceived social support, maternal stress, and socio- \\
Revised: 2021-04-20 & economic status on the quality of life of mothers of \\
Accepted: 2021-05-31 & children with intellectual disability in Oyo State, Nigeria. \\
& A total of 93 mothers of children with intellectual \\
& disability were respondents to a structured \\
Keywords: children with & questionnaire. Findings revealed that perceived social \\
intellectual disability, & support and socio-economic status had a significant \\
maternal stress, perceived & positive relationship with the quality of life of mothers of \\
social support, socio- & children with intellectual disability. Results showed that \\
economic status, quality of & the relationship between maternal stress and quality of \\
life & life was both negative and significant. Moreover, the \\
& study revealed that perceived social support made the \\
& highest relative contribution to the quality of life of \\
& mothers, followed by socio-economic status, and with \\
& maternal stress having the least effect. Furthermore, the \\
joint contribution of perceived social support, maternal & stress, and socio-economic status on the quality of life of \\
mothers was significant. These three variables should, \\
therefore, be given proper consideration for the \\
enhancement of the quality flife of mothers of children \\
with intellectual disability.
\end{tabular}




\section{Introduction}

The birth of a child with intellectual disability is likely to have a significant impact on family interactions and the lives of family and friends if not managed properly. The resulting effect may be observed by monitoring the mothers' quality of life (QOL). This may be due to children with intellectual disability requiring more care, resulting in the parents experiencing increasingly stressful situations in taking care of them. ${ }^{1}$ Studies have shown that the level of emotional stress and depression among families of children with disabilities is high. ${ }^{2}$ Such reactions are because the child's condition represents a deviation from the expectations of the parents. This, in turn, has a significant negative impact on their QOL. Thus, identifying factors that predict the QOL of mothers of children with intellectual disability may be of interest in designing community services that could help provide greater support for mothers.

In line with this, evaluation of the mother's QOL can serve as a reference for organizational improvement in terms of support services. ${ }^{3}$ Quality of life refers to the individual's expectations of well-being in various areas of their life, such as physical function, psychological development, and social interaction. ${ }^{4}$ Previous research results have shown that feelings of insufficiency, helplessness and guilt are felt by parents of children with disabilities. ${ }^{5}$ In addition to causing feelings of guilt, the birth of a child with disabilities can adversely affect the relationship between the parents. ${ }^{6}$ Additional strain and anxiety due to shifts in family structures are likely to affect the mother's QOL in

1 Sunil Karande and S. Kulkarni, "Quality of Life of Parents of Children with Newly Diagnosed Specific Learning Disability." Journal of Postgraduate Medicine 55, no. 2 (2009): 97-103. https://doi.org/10.4103/0022-3859.52839.

2 A. Bahar, G. Bahar, H. A. Savaş and S. Parlar. "Engelli Çocukların Annelerinin Depresyon ve Anksiyete Düzeyleri ile Stresle Başa Çıkma Tarzlarının Belirlenmesi" (Determination of Depression and Anxiety Levels, and Stress Coping Styles of Mothers of Children with Disabilities). Firat Sağlık Hizmetleri Dergisi 4 (2009), 97-112; Burcu Çakaloz and Semra Kurul, "The Investigation of Duchenne Muscular Dystrophy Children's Family Functions and their Mothers' Depression and Anxiety Levels." Turkish Journal $\begin{array}{lllllll}\text { of Clinical } & \text { Psychiatry } & 8, & \text { no } & 1 & \text { (2005): } & \text { 240. }\end{array}$ https://www.klinikpsikiyatri.org/en/jvi.aspx?pdir=kpd\&plng=eng\&un=KPD-66178; F. Dereli and S. Okur, "Engelli Çocuğa Sahip olan Ailelerin Depresyon Durumunun Belirlenmesi" (Determination of Depression Status of Families with Disabled Children). Yeni Tıp Dergisi 25, (2008): 164-8.

3 Xiaoyi Hu, M. Wang and X. Fei, "Family Quality of Life of Chinese Families of Children with Intellectual Disabilities." Journal of Intellectual Disability Research 56, no. 1 (2011): 30-44. https://doi.org/10.1111/j.1365-2788.2011.01391.X.

4 Vittoria Buratta et al., EUROHIS - Developing Common Instruments for Health Surveys. (Copenhagen: WHO Europe, 2003).

${ }^{5}$ Dervishaliaj Parental stress in families of children with disabilities: A literature review. Journal of Educational and Social Research, 3 no. 7 (2013) 579 - 584

${ }^{6}$ Isack Kande and Joav Merrick, "The Birth of a Child with Disability. Coping by Parents and Siblings," The Scientific World Journal 20, no. 3 (2003): 741-750, https://doi.org/10.1100/tsw.2003.63 
relation to other family members, as the mother would have to pay more attention to the social, educational and medical needs of the child.

The child will have to have to depend on the parents, in most cases, the mother. This significantly limits her independence and freedom. ${ }^{7}$ It may become even more frustrating because the child may not be able to fulfill the expectations of the parents due to the child's inability to attain the developmental milestones of others. Women carry the greater responsibility of raising children in most developing communities around the world, with mothers serving most often as the child's primary caregivers. ${ }^{8}$ Effective management of issues associated with taking care of children with intellectual disabilities will have a more severe impact on the QOL of mothers than on that of the fathers. ${ }^{9}$ There are, however, other factors that predict the QOL of mothers of children with intellectual disability, such the perceived social support, maternal stress, and socio-economic status of mothers. Therefore, the purpose of this research was to investigate the relationship existing between the perceived social support, maternal stress, and socio-economic status in predicting the perceived QOL of mothers of children with intellectual disability.

The purpose of this study is to identify and analyze the links between dependent variables (perceived social support, maternal stress, and socio-economic status), and perceived QOL among mothers of children with intellectual disability.

\section{Literature Review}

\section{Perceived Social Support and Quality of Life}

There is a possibility that perceived social support received by mothers of children with intellectual disability can influence their QOL. Perceived social support as a variable is vital in minimizing the potential psychological effects associated with raising children with intellectual disability. ${ }^{10} \mathrm{~A}$ general perception prevails that the negative effect of stressful situations on the QOL of a mother can be minimized through perceived social

${ }^{7}$ Kande and Merrick, "The Birth of a Child," 741-750.

${ }^{8}$ Kadriye Ones et al., "Assessment of the Quality of Life of Mothers of Children with Cerebral Palsy (primary caregivers)," Neurorehabilitation and Neural Repair 19, no. 3 (2005): 232-237, https://doi.org/10.1177/1545968305278857.

${ }_{9}^{9}$ Heykyung Oh and Eun-Kyoung Othelia Lee, "Caregiver Burden and Social Support Among Mothers Raising Children with Developmental Disabilities in South Korea." International Journal of Disability, Development and Education 56, no. 2 (2009): 149-67, https://doi.org/10.1080/10349120902868624.

${ }^{10}$ I. Aras, The Quality of Life of Parents of Children with Hearing Impairments and Speech, Doctoral thesis, Zagreb University School of Medicine in Zagreb, 2004; Somer Bishop, Jennifer Richler, Albert C. Cain, and Catherine Lord, "Predictors of Perceived Negative Impact in Mothers of Children with Autism Spectrum Disorder." American Journal of Mental Retardation 112, no. 6 (2007): 450-61, https://doi.org/10.1352/0895-8017(2007)112[450:POPNII]2.0.C0;2; U. Ozkubat, et al., "Otizme Yolculuk: Otizmli Çocuğa Sahip Ebeveynlerin Sosyal Destek Algılarına Ilişkin Görüşleri,” 323-48. 
support. ${ }^{11}$ Some studies have shown that perceived social support not only directly improves QOL, but that it also has an indirect positive impact in facilitating the victims' recovery which, in turn, will enhance their QOL.12 Despite these good intentions, however, perceived social support does not also have a positive correlation on QOL if poorly implemented. ${ }^{13}$ The effect of inadequate perceived social support on the wellbeing of an individual is significant.

Studies have revealed that factors such as cultural context, life events, individual characteristics, and the relationship between the provider and recipient of perceived social support, will determine the appropriateness of perceived social support. ${ }^{14}$ Mothers of children with intellectual disability may require perceived social support most of the time, irrespective of the child's age, because of delays in the cognitive development of the child. Perceived social support that is effectively provided will be of benefit to both the mothers' QOL and the development of their children. ${ }^{15}$ Getting the required perceived social support may be hampered by family income. Low socio-economic status does not have the same impact on mothers of children with intellectual disability when compared with mothers of children with typical development. The difference can be observed in areas such as QOL, productivity, condition of housing, psychological adjustment, and their relationship with the people in their community. ${ }^{16}$ Subjective support is more effective in improving post-traumatic stress disorder in comparison to objective support. ${ }^{17}$

11 Christine Charyton et al., "The Impact of Social Support on Health Related Quality of Life in Persons with Epilepsy," Epilepsy \& Behavior 16 no. 4 (2009): 640-645, https://doi.org/10.1016/j.yebeh.2009.09.011.

12 Lyinn Chung, Ay-Woan Pan, and Ping-Chuan Hsiung, "Quality of Life for Patients with Major Depression in Taiwan: A Model-based Study of Predictive Factors," Psychiatry Research 168 no. 2 (2009): 153-162. https://doi.org/10.1016/i.psychres.2008.04.003.

13 Chronister, Johnson, and Berven "Measuring social support in rehabilitation. Disability and Rehabilitation", An International, Multidisciplinary Journal, 28 no 2 (2006) 75-84. https://doi.org/10.1080/09638280500163695

14 Chronister, Johnson and Berven, "Measuring social support in rehabilitation. Disability and Rehabilitation", An International, Multidisciplinary Journal, 28 no 2 (2006) 75-84. https://doi.org/10.1080/09638280500163695 ; Jung-won Lim, and Brad Zebrack, "Different Pathways in Social Support and Quality of Life between Korean American and Korean Breast and Gynecological Cancer Survivors," Quality of Life Research 17, no. 5 (2008): 679-689, https://doi.org/10.1007/s11136-008-93434; Dean VonDras et al., "Effects of Culture and Age on the Perceived Exchange of Social Support Resources," The International Journal of Aging and Human Development 67, no. 1 (2008): 63-100, https://doi.org/10.2190/AG.67.1.d.

15 Ö Ersoy and N. Çürük, "Özel gereksinimli çocuğa sahip annelerde sosyal desteğin önemi” (The Importance of Social Support for the Mothers of the Children who have Special Needs), Sosyal Politika Çalışmaları Dergisi 17, (2009): 104-10. http://dergipark.gov.tr/download/article-file/198189.

16 Jiyeon Park, Ann P. Turnbull, and H. Rutherford Turnbull, III, "Impacts of Poverty on Quality of Life in Families of Children with Disabilities," The Council for Exceptional Children 68, no. 2 (2002): 151170. https://doi.org/10.1177/001440290206800201.

17 Shuidong Feng, et al., "Social Support and Posttraumatic Stress Disorder among Flood Victims in Hunan, China," Annals of Epidemiology 17, no. $10 \quad$ (2007): 827-833. https://doi.org/10.1016/j.annepidem.2007.04.002. 


\section{Maternal Stress and Quality of Life}

The QOL of mothers of children with intellectual disability can be affected significantly by maternal stress. Current findings on the extent of maternal stress in families with children with severe health challenges and developmental disorder are inaccurate. ${ }^{18}$ Some studies have shown that, when compared to parents of healthy children, the level of stress among parents of children with severe health challenges, for example parents of children with juvenile rheumatoid arthritis and kidney disease, are not the same. ${ }^{19}$

Behavioral problems were reported to have the most significant effect on maternal stress in a study that investigated QOL among parents of children with cerebral palsy. ${ }^{20}$ Moreover, financial difficulties will lead to increased frustration among mothers of children with intellectual disability, because of their inability to meet the needs of their children. ${ }^{21}$ The resulting effect is that maternal stress will set in, which will, in turn, have an impact on the mother's QOL.

Increased maternal stress can be attributed to insufficient perceived social support services for mothers, and the denial of their human rights. Findings have revealed that perceived support services and general resources can significantly reduce levels of stress among mothers. ${ }^{22}$ Reduction of maternal stress is important in the provision of proper care to the child with intellectual disability, and to the mother's QOL. In addition, it has been stated that the availability of perceived social support to families with children with intellectual disability significantly predicted their QOL, while perceived social support is positively associated with QOL. ${ }^{23}$ The QOL of caregivers of children with

${ }^{18}$ Betty Carter and Monica McGoldrick, eds., The Expanded Family Life Cycle (3rd ed) (Boston: Allyn and Bacon, 2005).

${ }^{19}$ Janeen C. Manuel, Janeen C., "Risk and Resistance Factors in the Adaptation in Mothers of Children with Juvenile Rheumatoid Arthritis," Journal of Pediatric Psychology 26, no. 4 (2001): 237-46. https://doi.org/10.1093/jpepsy/26.4.237; Elizabeth Soliday, Elizabeth Kool, and Marc B. Lande. "Psychosocial Adjustment in Children with Kidney Disease." Journal of Pediatric Psychology 25, no. 2 (2000): 93-103. https://doi.org/10.1093/jpepsy/25.2.93.

20 Reaz Mobarak, et al., "Predictors of Stress in Mothers of Children with Cerebral Palsy in Bangladesh," Journal of Pediatric Psychology 25, no. 6 (2000): 427-33. https://doi.org/10.1093/jpepsy/25.6.427.

21 Dervishaliaj Parental stress in families of children with disabilities: A literature review. Journal of Educational and Social Research, 3 no. 7 (2013) 579 - 584; Edith H. Luther, Daryl L. Canham, and Virginia Young Cureton, "Coping and Social Support for Parents of Children with Autism," Journal of School Nursing 21, no. 1 (2005): 40-7. https://doi.org/10.1622/1059-8405(2005)021[0040:cassfp]2.0.co;2.

22 M. Meppelder, et al., "Parenting Stress and Child Behaviour Problems Among Parents with Intellectual Disabilities: The Buffering Role of Resources," Journal of Intellectual Disability Research 59, no. 7 (2015): 664-677, https://doi.org/10.1111/jir.12170.

${ }^{23}$ Kate Davis and Susana Gavidia-Payne, "The Impact of Child, Family, and Professional Support Characteristics on the Quality of Life in Families of Young Children with Disabilities," Journal of Intellectual and Developmental Disability 34, no. 2 (2009): 153-62. https://doi.org/10.1080/13668250902874608 
intellectual disability is reported to have been influenced by variables such as parental wellbeing, family income, and depression, exacerbated by inadequate perceived social support. $^{24}$

Psychological stress theory suggests that traumatic life experiences have a detrimental impact on mental wellbeing and physical health and are linked to social influences. In alignment with the theory, most studies on QOL have investigated the correlation between QOL and stress in previous studies. ${ }^{25}$ Mothers of children with disabilities are more likely to find fault in themselves for having such children, and this will have an impact on their personal, social, and psychological well-being.

\section{Socio-economic Status and Quality of Life}

Previous research on the QOL of mothers seems to focus on mothers of children with developmental disabilities. The effects of their socio-economic status marital fulfilment and the different forms of developmental disorder on the QOL of mothers of children with neurodevelopmental disorders in Iran are significant. ${ }^{26}$ The QOL of families, especially of mothers, is discussed with respect to their financial aspects, health, value, occupation, and the individual support dimensions of developmental disabilities. ${ }^{27}$ In a study conducted by Ahmadizadeh et al., 28 income was identified as an underlying factor along with other variables that affect QOL, but the relationship was not significant. While income is a key component of socio-economic status, the position of other factors, such

24 Jin-Ding Lin et. al. "Quality of Life and Caregivers of Children and Adolescents with Intellectual Disabilities: Use of WHOQOL-BREF Survey." Research in Developmental Disabilities 30, no. 6 (2009): 14481458. https://doi.org/10.1016/j.ridd.2009.07.005.

25 Ying Lau and Lei Yin, "Maternal, Obstetric Variables, Perceived Stress and Health-Related Quality of Life Among Pregnant Women in Macao, China," Midwifery 27, no. 5 (2011): 668-673, https://doi.org/10.1016/j.midw.2010.02.008; Sara Shishehgar et al., "Perceived Pregnancy Stress and Quality of Life Amongst Iranian Women," Global Journal of Health Science 6, no. 4 (2014): 270-7, https://doi.org/10.5539/gihs.v6n4p270.

26 Mohammad Khayatzadeh Mahani, Hamid Reza Rostami, and Seyfolla Jahantabi Nejad, "Investigation of Quality of Life Determinants Among Mothers of Children with Pervasive Developmental Disorders in Iran," Hong Kong Journal of Occupational Therapy 23, no. 1 (2013): 14-19. https://doi.org/10.1016/j.hkjot.2013.03.002.

27 P. M. Ajuwon and I. Brown, "Family Quality of Lfe in Nigeria," Journal of Intellectual Disability Research 56, no. 1 (2012): 61-70, https://onlinelibrary.wiley.com/doi/full/10.1111/i.13652788.2011.01487.x

28 Zahra Ahmadizadeh, et al., "Factors Associated with Quality of Life in Mothers of Children with Cerebral Palsy in Iran," Hong Kong Journal of Occupational Therapy 25, no. 1, (2015): 15-22, https://doi.org/10.1016/j.hkjot.2015.02.002. 
as education, the number of children in the family, and occupation, is also crucial to the improvement of an individual's QOL. ${ }^{29}$

Multicultural studies have shown that ethnicity, gender, religion, and socioeconomic status of the families of children with disabilities are important factors that have significant influence on the QOL of caregivers. ${ }^{30}$ Improvements in the health of women and education are considered macro-level catalysts for long-term economic growth. ${ }^{31}$ The implication is that income and substitution impacts were partially mediated by each other. Moreover, through the intergenerational transmission of socioeconomic status, higher maternal socio-economic status at a micro level may result in better outcomes for a woman's own children.

\section{Method}

The descriptive survey research adopted an ex post facto design for the study. This was because it examined independent variables that already existed with an independent variable that cannot be manipulated.

\section{Participants}

Respondents for the study comprised 93 mothers of children with intellectual disability selected from 6 special schools in the Nigerian states of Oyo and Lagos. A purposive sampling technique was adopted for selection of samples from 3 schools from the two states to ensure geographic coverage, while respondents were selected using a random sampling technique. The mean age of respondents was 35.2 years ( $\mathrm{SD}=5.7$ ).

\section{Description of instrument}

Data was collected using a structured questionnaire tagged Predictors of Mother's Quality of Life (PMQL) [ $\alpha=0.899]$, with sections A-E. Section A was the demographic section that sought information, such as age, marital status, and type of employment from the respondents. Section B was a questionnaire of twenty-five items, the Family Quality of Life Scale, developed by Beach Center. ${ }^{32}$ Response was provided on a 5-point Likert

29 Janet Dzator, "Hard Times and Common Mental Health Disorders in Developing Countries: Insights from Urban Ghana," The Journal of Behavioral Health Services \& Research 40, no. 1 (2013): 71-87, https://doi.org/10.1007/s11414-012-9305-z.

30 Oh and Lee, "Caregiver Burden and Social Support,"149-67.

31 Kirrin Gill, Rohini Pande, and Anju Malhotra, "Women Deliver for Development," The Lancet 370, no. 9595 (2007): 1347-1357, https://doi.org/10.1016/S0140-6736(07)61577-3; Kristine Husøy Onarheim, Johanne Helene Iversen, and David E. Bloom, “Economic Benefits of Investing in Women's Health: A Systematic Review," PloS ONE 11, no. 3 (2016): e0150120. https://doi.org/10.1371/journal.pone.0150120.

32 Beach Center on Disabilities. Family Quality of Life Scale. Lawrence, KS, USA: Beach Center on Disabilities, 2015. 
scale $(1=$ not at all important, $5=$ very important). Section $C$ contained the twelve-items of perceived social support, as developed by Zimet, Dahlem, Zimet and Farley. ${ }^{33}$ Section D was the eight-point scale used for collection of information on the socio-economic status of respondents by asking questions related to the level of education, residence, and types of appliances present in the home. Section E contained ten items in a questionnaire, used for collection of data on the perceived stress level developed by Cohen and Williamson. ${ }^{34}$ This also consisted of a 5-point Likert scale, ranging from $0=$ Never to $4=$ Very Often. Respondents were expected to respond based on their feelings and thoughts in the last month preceding their answers to the questionnaire.

\section{Ethical consideration}

A trained research assistant used the participants' native language to inform them of the purpose of the study. In accordance with research ethics, the research assistant presented a printed consent form written in English to each participant. After ensuring sufficient comprehension, each participant completed and signed the consent form. Participants were told that their profiles and answers would be kept private. Permission to perform this study was obtained and granted by the Oyo State branch of the Parents Teacher Association. Thus, the study adhered to the ethics of research confidentiality.

\section{Data Analysis}

The IBM SPSS statistical program version 22.0 for Windows was used for analyzing the data collected. Data was analyzed in terms of descriptive and inferential statistics of the Pearson's product moment correlation coefficient. The relationships between perceived social support, maternal stress, and socio-economic status, and perceived QOL among mothers of children with intellectual disability, were determined using the Pearson's product moment correlation coefficient. Furthermore, to determine the contributions made towards the perceived social support, maternal stress, and socio-economic status on the perceived QOL among mothers of children with intellectual disability, multiple regression was utilized.

33 Gregory D. Zimet et al., "The Multidimensional Scale of Perceived Social Support," Journal of Personality Assessment 52 no. 1 (1988): 30-41, https://doi.org/10.1207/s15327752jpa5201 2.

34 S. Cohen and G. Williamson, "Perceived Stress in a Probability Sample of the United States," in The Social Psychology of Health, eds S. Spacapan and S. Oskamp, (Newbury Park, CA: Sage, 1988). 


\section{Results and Discussion}

Demographic data collected from the respondents was analysed using descriptive statistics of frequency counts and simple percentage, which revealed that a total of 31 women (33.3\%) in the age range of below 24 years old, 14 (15.1\%) $25-29$ years of old, 9 (9.7\%) 30 - 34 years, 13 (14.0\%) 45 - 49 years old, 15 (16.1\%) $45-49 \%$ and $11(11.8 \%)$ in age of 50 years old and above, participated in the study. Among them $40.9 \%$ were single, $49.5 \%$ married, and the divorced and widowed were 4.3 and $5.4 \%$ respectively. Furthermore, the demographic information showed that $26.5 \%$ were unemployed, $32.3 \%$ were self-employed, $31.2 \%$ were in full time employment, and $9.7 \%$ were in part time employment.

Table 1: Correlation between perceived social support, maternal stress and socio-economic status and perceived QOL of mothers of individuals with intellectual disability

\begin{tabular}{lcccc}
\hline & $\begin{array}{c}\text { Mother } \\
\text { Quality of } \\
\text { Life }\end{array}$ & $\begin{array}{c}\text { Perceive } \\
\text { d social } \\
\text { support }\end{array}$ & $\begin{array}{c}\text { Socio- } \\
\text { economic } \\
\text { status }\end{array}$ & $\begin{array}{c}\text { Maternal } \\
\text { Stress }\end{array}$ \\
\hline $\begin{array}{l}\text { Mother Quality of } \\
\text { Life }\end{array}$ & 1 & $.451^{* *}$ & $.254^{*}$ & $-.209^{*}$ \\
\hline $\begin{array}{l}\text { Perceived social } \\
\text { support }\end{array}$ & 1 & .049 & -.009 \\
\hline $\begin{array}{l}\text { socio-economic } \\
\text { status }\end{array}$ & & & 1 & $-.256^{*}$ \\
\hline Maternal stress & & & 1 \\
\hline$* *$ Correlation is significant at the 0.01 level (2-tailed). & & \\
\hline *. Correlation is significant at the 0.05 level (2-tailed). & & \\
\hline
\end{tabular}

Using Pearson moment correlation coefficient, it was observed that perceived social support $\left(r=0.451^{* *}, p>0.01\right)$, socio-economic status $\left(r=0 . .254^{*}, p>0.05\right)$ and maternal stress $\left(r=-0.209^{* *}, p>0.01\right)$ had a significant association with the mother's QOL. Although the relationship between maternal stress and the mother's QOL was negative, this implies that a decrease in maternal stress would lead to improved QOL for mothers of children with intellectual disability. Moreover, the result revealed that the mother's QOL had a positive relationship with her perceived social support and socio-economic status. The implication is that increased perceived social support and improved socioeconomic status would lead to improvement in the mother's QOL. Therefore, there is a strong link between the independent variables (perceived social support and socioeconomic status) and the mother's QOL. However, the relationship between the independent variables (perceived social support, maternal stress, and socio-economic status) and mother's quality of life was not significant. 
Table 2: Joint relationship between perceived social support, maternal stress socioeconomic status and perceived QOL of mothers of individuals with intellectual disability

\begin{tabular}{llrcrr}
\hline Model & $\begin{array}{c}\text { Sum of } \\
\text { Squares }\end{array}$ & Df & $\begin{array}{c}\text { Mean } \\
\text { Square }\end{array}$ & F & Sig. \\
\hline $\begin{array}{l}\text { Regressi } \\
\text { on }\end{array}$ & 7469.212 & 3 & 2489.737 & 11.51 & \\
\hline Residual & 19243.778 & 89 & 216.222 & & $.000^{\mathrm{b}}$ \\
\hline Total & 26712.989 & 92 & & \\
\hline
\end{tabular}

Multiple regression was used to analyse the second and third research questions, which reveal both the joint relationship (Table 2) and relative contribution (Table 3) of perceived social support, maternal stress, and the mother's socio-economic status to the mother's QOL. Table 2a reveals the joint prediction of the three independent variables to the mother's quality of life. That is, the three predictor variables which jointly influenced the mother's QOL. The table also shows a coefficient of multiple correlations (R) of 0.529a and a multiple $\mathrm{R}$ square of .280. This means that $28 \%$ was accounted for by the three predictor variables of the variance in the mother's quality of life, when taken together. The significance of the composite contribution was tested at $p<0.05$ using the F-ratio at the degree of freedom ( $d f=3 / 89)$. The table equally indicates that the Analysis of Variance for the regression yielded an F-ratio of 11.515 (significant at 0.05 level). This implies that perceived social support, maternal stress, and socio-economic status jointly contribute to the mother's QOL.

Table 3: Relative contribution of perceived social support, maternal stress and the mother's socio-economic status to the mother's QOL

\begin{tabular}{|c|c|c|c|c|c|}
\hline \multirow[t]{2}{*}{ Model } & \multicolumn{2}{|c|}{$\begin{array}{l}\text { Unstandardized } \\
\text { Coefficients }\end{array}$} & \multirow{2}{*}{\begin{tabular}{|c|c}
$\begin{array}{c}\text { Standar } \\
\text { dized } \\
\text { Coefficie } \\
\text { nts }\end{array}$ \\
Beta \\
\end{tabular}} & \multirow[t]{2}{*}{$T$} & \multirow[t]{2}{*}{ Sig. } \\
\hline & B & $\begin{array}{l}\text { Std. } \\
\text { Error }\end{array}$ & & & \\
\hline 1 (Constant) & 56.513 & 15.671 & & 3.606 & .001 \\
\hline Perceived social support & .575 & .118 & .440 & 4.882 & .000 \\
\hline Mother's socio-economic status & .299 & .145 & .193 & 2.068 & .042 \\
\hline Maternal Stress & -.362 & .217 & -.155 & -1.669 & .099 \\
\hline
\end{tabular}


The relative contribution expressed as beta weights of the three independent variables to the dependent variable is captured in Table 3. The partial correlation coefficients of the perceived social support and socio-economic status were positively associated with the mother's QOL. There was, however, a negative partial correlation coefficient between maternal stress and the mother's QOL. Using the standardized regression coefficient to determine the relative contributions of the independent variables to the explanation of the dependent variable, this study, as observed in Table 3, shows that perceived social support, was highly significant to the QOL of mothers of individuals with intellectual disability $(\beta=0.440, t=4.882, p<0.05)$ while the mother's socio-economic status contribution to the mother's QOL $(\beta=-0.193, \mathrm{t}=2.068, p<0.05)$ was marginally significant. However, the relative contribution of maternal stress to the mother's QOL was not significant $(\beta=-0.155, t=-1.669, p>0.05)$. The relative contribution of maternal stress status to the QOL of mothers of individuals with intellectual disability was negative. In essence, Table 3 shows that perceived social support and the mother's socio-economic status contributed to improved QOL experienced by mothers of individuals with intellectual disability. Table 3 shows that maternal stress contribution to QOL of mothers of individuals with intellectual disability was both negative and not significant.

\section{Discussion of Findings}

Prior to this study, informal discussions, and interactive discussions with mothers of individuals with intellectual disability in South-West Nigeria have shown that the birth of a child with intellectual disability has an impact on the need for perceived social support, and the maternal stress and socio-economic status of mothers. This may be due to the additional care that is required to be provided to children with intellectual disability when compared to their regular peers, and thus, results in poor QOL for the mother. Findings revealed that the level of emotional stress and depression is high among families of children with disabilities. ${ }^{35}$

Therefore, the results, based on the first research question, showed that perceived social support and socio-economic status predicted the mother's QOL. This study supports the conclusion of others who noted that perceived social support was an important variable required to reduce the possible psychological effects associated with raising children with intellectual disability. ${ }^{36}$ The assertion of Ersoy and Çürük ${ }^{37}$ aligns

${ }^{35}$ Bahar et al., "Engelli Çocukların Annelerinin Depresyon ve Anksiyete Düzeyleri ile Stresle Başa Çıkma Tarzlarının Belirlenmesi", 97-112; Çakaloz and Kurul, "The Investigation of Duchenne Muscular Dystrophy Children's Family Functions and their Mothers' Depression and Anxiety Levels" 24-30; Dereli and Okur, "Engelli Çocuğa Sahip olan Ailelerin Depresyon Durumunun Belirlenmesi", 164-8.

${ }^{36}$ Aras, The Quality of Life of Parents of Children with Hearing Impairments and Speech; Bishop et al., "Predictors of Perceived Negative Impact in Mothers of Children with Autism Spectrum Disorder," 45061; Ozkubat, et al., "Otizme Yolculuk: Otizmli Çocuğa Sahip Ebeveynlerin Sosyal Destek Algılarına Ilişkin Görüşleri," 323-48.

${ }^{37}$ Ersoy and Çürük, “Özel gereksinimli çocuğa sahip annelerde sosyal desteğin önemi” 104-10. 
with the findings that perceived social support, when effectively provided, would be of benefit to both the mother's QOL and the development of the child. The study supports the assertion that improvements in the health of women and education are considered macro-level catalysts for long-term economic growth. ${ }^{38}$ Dervishaliaj, ${ }^{39}$ and Luther, Canham and Cureton, ${ }^{40}$ noted that financial difficulties would lead to increased frustration among mothers of children with intellectual disability, because of their inability to meet the needs of their child.

In response to the second research question, this study noted that perceived social support, maternal stress, and socio-economic status jointly contributed to QOL of mothers of children with intellectual disability. QOL of mothers in this study is perceived as a psychological factor that is influenced by perceived social support, maternal stress, and socio-economic status. The finding agrees with the reports of others that such variables as cultural context, life events, individual characteristics, and the relationship between provider and recipient of perceived social support, would determine the appropriateness of perceived social support. ${ }^{41}$ Gill, Pande, and Malhotra ${ }^{42}$ and Onarheim, Iversen, and Bloom, ${ }^{43}$ agree that improvements in the health of women and their education are considered macro-level catalysts for long-term economic growth. Ahmadizadeh et al., ${ }^{44}$ identified income as an underlying variable, along with other factors that predict QOL.

This contribution of the independent variables to the QOL of mothers of children with intellectual disability was identified in the study. The outcome revealed that the perceived social support and socio-economic status of mothers was positive and significant to their QOL. When compared, the contribution of perceived social support to QOL was higher than that of socio-economic status. The implication is that perceived social support and its associated factors are significant in predicting the QOL of mothers of children with intellectual disability. This finding aligns with $\mathrm{Oh}$ and Lee, ${ }^{45}$ that gender, religion, and the socio-economic status of families of children with disabilities are variables which significantly influence the QOL of caregivers, including mothers.

38 Gill, Pande, and Malhotra, "Women Deliver for Development," 1347-1357; Onarheim, Iversen, and Bloom, "Economic Benefits of Investing in Women's Health," e0150120.

${ }^{39}$ Dervishaliaj Parental stress in families of children with disabilities: A literature review. Journal of Educational and Social Research, 3 no. 7 (2013) 579 - 584

40 Luther, Canham, and Cureton, "Coping and Social Support for Parents of Children with Autism," 40-7.

41 Chronister, J. K, E. K. Johnson, and Berven, N. L. "Measuring social support in rehabilitation. Disability and Rehabilitation", An International, Multidisciplinary Journal, 28 no 2 (2006) 75-84. https://doi.org/10.1080/09638280500163695 ; Lim and Zebrack, "Different Pathways in Social Support and Quality of Life," 679-689; VonDras et al., "Effects of Culture and Age," 63-100.

42 Gill, Pande, and Malhotra, "Women Deliver for Development," 1347-1357.

43 Onarheim, Iversen, and Bloom, "Economic Benefits of Investing in Women's Health," e0150120.

44 Ahmadizadeh, et al., "Factors Associated with Quality of Life in Mothers of Children with Cerebral Palsy in Iran," 15-22.

45 Oh and Lee, "Caregiver Burden and Social Support,"149-67. 
Chronister, Johnson and Berven, ${ }^{46}$ Lim and Zebrack, ${ }^{47}$ and VonDras, Pouliot, Malcore and Iwahashi, ${ }^{48}$ claim that the interaction between the provider and recipient of perceived social support would determine the appropriateness of the perceived social support. Thus, perceived social support as a variable is crucial in minimizing the potential psychological effects associated with raising children with intellectual disability. ${ }^{49}$

\section{Conclusion}

The effect of perceived social support, maternal stress, and socio-economic status on the QOL of mothers of children with intellectual disability was acknowledged in this study. It was further established that perceived social support and socio-economic status have significant relative effectiveness on the QOL of mothers, while the relative contribution of maternal stress of QOL on mothers of children with intellectual disability was not significant. Based on the findings, the conclusion is that perceived social support, maternal stress and socio-economic status had a joint effect on the QOL of mothers of children with intellectual disability. The relationship between maternal stress and QOL of mothers was observed to be negative, which shows that a decrease in maternal stress will result in improved QOL of mothers of children with intellectual disability.

\section{Limitations}

Generalizability of the findings is limited by the number of respondents and the descriptive research design adopted in the study. The study investigated the relationship between the independent variables (support services, maternal stress, and socioeconomic status) and the QOL of mothers of children with intellectual disability in Nigeria. The findings may be restricted to mothers of children with intellectual disability, and not to the general population.

It must be noted that the researchers do not know of other studies that investigated the relationship between dependent variables (perceived social support, maternal stress, and socio-economic status) and QOL of mothers of children with intellectual disability in Nigeria. The results should, therefore, be interpreted with caution.

${ }^{46}$ Chronister. Johnson, and Berven,. "Measuring social support in rehabilitation. Disability and Rehabilitation", An International, Multidisciplinary Journal, 28 no 2 (2006) 75-84. https://doi.org/10.1080/09638280500163695

${ }^{47}$ Lim and Zebrack, "Different Pathways in Social Support", 679-689.

${ }^{48}$ VonDras et al., "Effects of Culture and Age," 63-100.

${ }^{49}$ Aras, The Quality of Life of Parents of Children with Hearing Impairments and Speech; Bishop et al., "Predictors of Perceived Negative Impact in Mothers of Children with Autism Spectrum Disorder," 45061; Ozkubat, et al., "Otizme Yolculuk: Otizmli Çocuğa Sahip Ebeveynlerin Sosyal Destek Algılarına Ilişkin Görüşleri," 323-48. 
Funding: This work was supported by the South African Research Chairs Initiative of the Department of Science and Innovation and National Research Foundation of South Africa. South African Research Chair, Education and Care in Childhood, Faculty of Education, University of Johannesburg South Africa [grant number: 87300, 2017].

\section{Acknowledgments}

The authors acknowledge the mothers of children with intellectual disability who responded to the questionnaire, the authors whose materials they consulted, and Mrs. Mojisola O. Udeme-Jacob for her support in ensuring that the study was carried out.

\section{Conflict of Interest}

The authors confirm that there is no conflict of interest with respect to the data presented in this paper.

\section{Reference}

Ahmadizadeh, Zahra, Mehdi Rassafiani, Mohammad Amozadeh Khalili, and Majid Mirmohammadkhani. "Factors Associated with Quality of Life in Mothers of Children with Cerebral Palsy in Iran." Hong Kong Journal of Occupational Therapy 25, no. 1, (2015): 15-22. https://doi.org/10.1016/j.hkjot.2015.02.002.

Ajuwon, P. M., and I. Brown. "Family Quality of Lfe in Nigeria." Journal of Intellectual Disability Research 56, no. 1 (2012): 61-70. https://onlinelibrary.wiley.com/doi/full/10.1111/j.1365-2788.2011.01487.x.

Aras, I. The Quality of Life of Parents of Children with Hearing Impairments and Speech. Doctoral thesis, Zagreb University School of Medicine in Zagreb, 2004.

Bahar, A., G. Bahar, H. A. Savaş, and S. Parlar. "Engelli Çocukların Annelerinin Depresyon ve Anksiyete Düzeyleri ile Stresle Başa Çıkma Tarzlarının Belirlenmesi" (Determination of Depression and Anxiety Levels, and Stress Coping Styles of Mothers of Children with Disabilities). Furat Sağlık Hizmetleri Dergisi 4 (2009), 97112.

Beach Center on Disabilities. Family Quality of Life Scale. Lawrence, KS, USA: Beach Center on Disabilities, (2015).

Bishop, Somer L., Jennifer Richler, Albert C. Cain, and Catherine Lord. "Predictors of Perceived Negative Impact in Mothers of Children with Autism Spectrum 
Disorder." American Journal of Mental Retardation 112, no. 6 (2007): 450-61. https://doi.org/10.1352/0895-8017(2007)112[450:POPNII]2.0.CO;2

Buratta, Vittoria, Frova Luisa, Lidia Gargiulo, Emilio Gianicolo, Sabrina Prati, and Luciana Quattrociocchi. EUROHIS - Developing Common Instruments for Health Surveys. Copenhagen: WHO Europe, 2003.

Çakaloz, Burcu, and Semra Kurul. "The Investigation of Duchenne Muscular Dystrophy Children's Family Functions and their Mothers' Depression and Anxiety Levels." Turkish Journal of Clinical Psychiatry 8, no 1 (2005): 24-30. https://www.klinikpsikiyatri.org/en/jvi.aspx?pdir=kpd\&plng=eng\&un=KPD66178

Carter, Betty, and Monica McGoldrick, eds. The Expanded Family Life Cycle (3rd ed). Boston: Allyn and Bacon, 2005.

Charyton, Christine, John O. Elliott, Bo Lu, and J. Layne Moore. "The Impact of Social Support on Health Related Quality of Life in Persons with Epilepsy." Epilepsy \& Behavior 16 no. 4 (2009): 640-645.

https://doi.org/10.1016/j.yebeh.2009.09.011

Chronister, J. K, E. K. Johnson, and Berven, N. L. "Measuring social support in rehabilitation. Disability and Rehabilitation", An International, Multidisciplinary Journal, 28 no 2 (2006) 75-84. https://doi.org/10.1080/09638280500163695

Chung, Lyinn, Ay-Woan Pan, and Ping-Chuan Hsiung. "Quality of Life for Patients with Major Depression in Taiwan: A Model-based Study of Predictive Factors." Psychiatry Research 168 no. 2 (2009): 153-162. https://doi.org/10.1016/j.psychres.2008.04.003

Cohen, S., and G. Williamson, "Perceived Stress in a Probability Sample of the United States," in The Social Psychology of Health, edited by S. Spacapan and S. Oskamp. Newbury Park, CA: Sage, 1988.

Davis, Kate, and Susana Gavidia-Payne. "The Impact of Child, Family, and Professional Support Characteristics on the Quality of Life in Families of Young Children with Disabilities." Journal of Intellectual and Developmental Disability 34, no. 2 (2009): 153-62. https://doi.org/10.1080/13668250902874608.

Dereli, F., and S. Okur. "Engelli Çocuğa Sahip olan Ailelerin Depresyon Durumunun Belirlenmesi" (Determination of Depression Status of Families with Disabled Children). Yeni Tip Dergisi 25, (2008): 164-8. http://acikerisim.mu.edu.tr/xmlui/bitstream/handle/20.500.12809/7934/dere li.pdf?sequence $=1$

Dzator, Janet. "Hard Times and Common Mental Health Disorders in Developing Countries: Insights from Urban Ghana." The Journal of Behavioral Health Services 
\& Research 40, no. 1 (2013): 71-87. https://doi.org/10.1007/s11414-012-9305$\underline{\mathrm{Z}}$

Ersoy, Ö, and N. Çürük. “Özel gereksinimli çocuğa sahip annelerde sosyal desteğin önemi” (The Importance of Social Support for the Mothers of the Children who have Special Needs). Sosyal Politika Çalışmaları Dergisi 17, (2009): 104-10..

Feng, Shuidong, Hongzhuan Tan, Abuaku Benjamin, Shiwu Wen, Aizhong Liu, Jia Zhou, Shuoqi Li, et al. "Social Support and Posttraumatic Stress Disorder among Flood Victims in Hunan, China." Annals of Epidemiology 17, no. 10 (2007): 827-833. https://doi.org/10.1016/j.annepidem.2007.04.002.

Gill, Kirrin, Rohini Pande, and Anju Malhotra. "Women Deliver for Development." The Lancet 370, no. 9595 (2007): 1347-1357. https://doi.org/10.1016/S01406736(07)61577-3.

Hoffman, Lesa, Janet Marquis, Denise Poston, Jean Ann Summers, and Ann Turnbull. 2006. "Assessing Family Outcomes: Psychometric Evaluation of the Beach Center Family Quality of Life Scale." Journal of Marriage and Family 68(4): 1069-83. https://doi.org/10.1111/j.1741-3737.2006.00314.x.

Hu, Xiaoyi, M. Wang, and X. Fei, X.. "Family Quality of Life of Chinese Families of Children with Intellectual Disabilities." Journal of Intellectual Disability Research 56, no. 1 (2011): 30-44. https://doi.org/10.1111/j.1365-2788.2011.01391.x.

Kande, Isack, and Joav Merrick. "The Birth of a Child with Disability. Coping by Parents and Siblings." The Scientific World Journal 20, no. 3 (2003): 741-750. https://doi.org/10.1100/tsw.2003.63

Karande, Sunil., and S. Kulkarni. "Quality of Life of Parents of Children with Newly Diagnosed Specific Learning Disability." Journal of Postgraduate Medicine 55, no. 2 (2009): 97-103. https://doi.org/10.4103/0022-3859.52839

Lau, Ying, and Lei Yin. "Maternal, Obstetric Variables, Perceived Stress and HealthRelated Quality of Life Among Pregnant Women in Macao, China." Midwifery 27, no. 5 (2011): 668-673. https://doi.org/10.1016/j.midw.2010.02.008

Lim, Jung-won, and Brad Zebrack. "Different Pathways in Social Support and Quality of Life between Korean American and Korean Breast and Gynecological Cancer Survivors." Quality of Life Research 17, no. 5 (2008): 679-689. https://doi.org/10.1007/s11136-008-9343-4

Lin, Jin-Ding, Jung Hu. Chia-Feng Yen, Shang-Wei Hsu, Lan-Ping Lin, Ching-Hui Loh, MeiHua Chen, et. al. "Quality of Life and Caregivers of Children and Adolescents with Intellectual Disabilities: Use of WHOQOL-BREF Survey." Research in Developmental Disabilities 30, no. 6 (2009): 1448-1458. https://doi.org/10.1016/j.ridd.2009.07.005 
Luther, Edith H., Daryl L. Canham, and Virginia Young Cureton. "Coping and Social Support for Parents of Children with Autism." Journal of School Nursing 21, no. 1 (2005): $\quad 40-7$.

https://doi.org/10.1622/10598405(2005)021[0040:cassfp]2.0.co;2

Mahani, Mohammad Khayatzadeh, Hamid Reza Rostami, and Seyfolla Jahantabi Nejad. "Investigation of Quality of Life Determinants Among Mothers of Children with Pervasive Developmental Disorders in Iran." Hong Kong Journal of Occupational Therapy 23, no. 1 (2013): 14-19. https://doi.org/10.1016/j.hkjot.2013.03.002.

Manuel, Janeen C. "Risk and Resistance Factors in the Adaptation in Mothers of Children with Juvenile Rheumatoid Arthritis." Journal of Pediatric Psychology 26, no. 4 (2001): 237-46. https://doi.org/10.1093/jpepsy/26.4.237

Meppelder, M., M. Hodes, S. Kef, S., and C. Schuengel. "Parenting Stress and Child Behaviour Problems Among Parents with Intellectual Disabilities: The Buffering Role of Resources." Journal of Intellectual Disability Research 59, no. 7 (2015): 664677. https://doi.org/10.1111/jir.12170.

Meral, B. F., and A. Cavkaytar. 2015. "Otizmli Çocuk Ailelerinin Aile Yaşam Kalitesi Algilari" (The Perceptions of Family Quality of Life of Parents of Children with Autism). Kastamonu Ĕ̆itim Dergisi 23: 1363-80.

Mobarak, Reaz, Naila Z. Khan, Shirin Munir, Sultana S. Zaman, and Helen McConachie. "Predictors of Stress in Mothers of Children with Cerebral Palsy in Bangladesh." Journal of Pediatric Psychology 25, no. 6 (2000): 427-33.

https://doi.org/10.1093/jpepsy/25.6.427.

Oh, Heykyung, and Eun-Kyoung Othelia Lee. "Caregiver Burden and Social Support Among Mothers Raising Children with Developmental Disabilities in South Korea." International Journal of Disability, Development and Education 56, no. 2 (2009): 149-67 https://doi.org/10.1080/10349120902868624.

Ones, Kadriye, Ebru Yilmaz, BanuCetinkaya, and Nil Caglar. "Assessment of the Quality of Life of Mothers of Children with Cerebral Palsy (primary caregivers)." Neurorehabilitation and Neural Repair 19, no. 3 (2005): 232-237. https://doi.org/10.1177/1545968305278857.

Onarheim, Kristine Husøy, Johanne Helene Iversen, and David E. Bloom. "Economic Benefits of Investing in Women's Health: A Systematic Review." PloS ONE 11, no. 3 (2016): e0150120. https://doi.org/10.1371/journal.pone.0150120.

Ozkubat, U., S., Ozdemir, O. G. Selimoğlu, and G. Töret. “Otizme Yolculuk: Otizmli Çocuğa Sahip Ebeveynlerin Sosyal Destek Algılarına Ilişkin Görüşleri” (Journey to Autism: Opinions of Parents with Autistic Children on Social Support Perceptions). Ondokuz Mayıs Üniv Eğitim Fakültesi Dergisi 33 (2014): 323-48. 
Park, Jiyeon, Ann P. Turnbull, and H. Rutherford Turnbull, III. "Impacts of Poverty on Quality of Life in Families of Children with Disabilities." The Council for Exceptional Children 68, no. 2 (2002): https://doi.org/10.1177/001440290206800201.

Shishehgar, Sara, Mahrokh Dolatian, Hamid Majd, and Maryam Bakhtiary. "Perceived Pregnancy Stress and Quality of Life Amongst Iranian Women." Global Journal of Health Science 6, no. 4 (2014): 270-7. https://doi.org/10.5539/gjhs.v6n4p270.

Soliday, Elizabeth, Elizabeth Kool, Marc B. Lande. "Psychosocial Adjustment in Children with Kidney Disease." Journal of Pediatric Psychology 25, no. 2 (2000): 93-103. https://doi.org/10.1093/jpepsy/25.2.93.

Verdugo, M.A., L. Córdoba, and J. Gómez. 2005. "Spanish Adaptation and Validation of the Family Quality of Life Survey." Journal of Intellectual Disability Research 49 (10): 794-8. https://onlinelibrary.wiley.com/doi/full/10.1111/j.13652788.2005.00754.x.

VonDras, Dean, D. Gregory, S. Pouliot, Sylvia A. Malcore, and Shigetoshi Iwahashi. "Effects of Culture and Age on the Perceived Exchange of Social Support Resources." The International Journal of Aging and Human Development 67, no. 1 (2008): 63-100. https://doi.org/10.2190/AG.67.1.d.

Zimet, Gregory D., Nancy W. Dahlem, Sara G. Zimet, and Gordon K. Farley. "The Multidimensional Scale of Perceived Social Support." Journal of Personality Assessment $\quad 52 \quad$ no. 1 https://doi.org/10.1207/s15327752jpa5201_2. 